\title{
A Road Map on Biohydrogen Production from Organic Wastes
}

\author{
Debabrata Das ${ }^{1}$
}

Received: 2 December 2017 / Accepted: 8 December 2017 / Published online: 15 December 2017

(c) Indian National Academy of Engineering 2017

\begin{abstract}
Fossil fuels play important role in the economy of industrialized countries of the world. However, these sources of energy are not renewable and nearing the brink of extinction. Moreover, the reliance on these fuels has led to increased levels of pollution which have caused serious adverse impacts on the environment. Hydrogen has emerged as a promising alternative since it does not produce $\mathrm{CO}_{2}$ and also has the highest calorific value. The biological $\mathrm{H}_{2}$ production has an edge over its chemical counterpart mainly because it is environmentally benign. However, the major challenge limiting the transition from an oil based economy to that of biohydrogen is the low hydrogen production rate, yield and economy of the process. Biohydrogen production by dark fermentation is found most promising as compared to other biohydrogen production processes like photo fermentation process using photofermentative bacteria, microalgae, microbial fuel cell etc. Present research group has been involved in biohydrogen research for last two decades. Suitability of different organic wastes for the hydrogen production has been developed. Both pure microbial cultures and acidogenic cultures obtained from anaerobic digester are found suitable for the hydrogen production. One 10,000 L pilot plant studies are carried out for the commercial exploitation of the process. The spent medium of the dark fermentation process mostly comprises of acetic acid, butyric acid etc., which are the substrates for the biomethanation process for the generation of methane and carbon dioxide. So, maximization of gaseous energy is possible dark fermentation followed by methanation process which is known as biohythane process.
\end{abstract}

Keywords Biohydrogen $\cdot$ Dark fermentation $\cdot$ Photofermentation $\cdot$ Microbial fuel cell $\cdot$ Pilot plant $\cdot$ Biohythane

\section{Introduction}

Energy crisis is looming the global economy. Our energy requirements are almost fully provided from the carboncontaining fossil sources such as oil, coal and natural gas. The rapid consumption of these fossil resources has caused an accelerated release of the bound carbon as $\mathrm{CO}_{2}$. The rate at which fossil fuels are depleting, a necessity of alternate fuel has gained importance. The use of fossil fuels for energy is unsustainable and causes build-up of greenhouse gases in the atmosphere leading to global warming. The need of the hour is an efficient fuel with zero carbon footprints and this path can be achieved by using hydrogen. Biofuels can be harnessed easily. It can also be used in existing combustion engines after blending with

Debabrata Das

ddas.iitkgp@gmail.com

http://www.bioh2iitkgp.in

1 Department of Biotechnology, Indian Institute of Technology Kharagpur, Kharagpur, India petroleum diesel to various degrees. No separate transportation infrastructures would be required for such fuels. Hydrogen having highest energy density $\left(143 \mathrm{~kJ} \mathrm{~g}^{-1}\right)$, is a clean and environment friendly fuel. Dark fermentative $\mathrm{H}_{2}$ production using renewable resources (organic wastes) is a promising way of economical and sustainable energy source as compared to photobiological processes (Das and Veziroglu 2001). Dark fermentation of organic wastes may be carried out by mesophilic and thermophilic organisms. The dark fermentation at thermophilic temperatures $\left(60^{\circ} \mathrm{C}\right)$ has many advantages (Roy et al. 2014a, b). Many industrial organic wastewaters are discharged at elevated temperatures such as palm mill effluent, distillery effluent etc. that can be directly used. Moreover, at higher temperature condition leads to destruction of pathogens, lower risk of contamination by methanogenic Archaea, higher rate of hydrolysis and higher $\mathrm{H}_{2}$ yield. In addition, during fermentation generates excess heat that requires cooling for mesophilic cultures. Bioprocess engineering laboratory, Indian Institute of Technology Kharagpur is known for accentuating research on various routes of biohydrogen 
production in India (Das and Veziroglu 2008). Over the years, this lab has developed a comprehensive and refined expertise in the field biohydrogen production (Fig. 1). All the domains related to hydrogen production through biological routes have been explored.

The main objective of the research work is to improve the biohydrogen production process with main emphasis being to increase yields of hydrogen from the existing processes using organic wastes. A wide range of potential $\mathrm{H}_{2}$ producing microorganisms (which includes thermophiles and mesophiles) have already been identified. One such mesophile potential isolate, Enterobacter cloacae IIT BT08 (presently known as Klebsiela pneumonia) has been identified (Kumar and Das 2000). This organism produces hydrogen at high rate as compared to other mesophilic microbes. Redirection of the biochemical pathways of $K$. pneumonia IIT-BT08 is carried out for the improvement of the hydrogen production. It is done by blocking alcohol and some of the organic acids formation in K. pneumonia IIT-BT08 during their metabolisms (Kumar et al. 2001). The principle being that NADH is usually generated by catabolism of glucose to pyruvate through glycolysis. The conversion of pyruvate to ethanol, butanediol, lactic acid and butyric acid involves oxidation of NADH. The concentration of NADH would be increased if the formation of these metabolites could be blocked. Double mutants of K. pneumonia IIT-BT08 with defects in both alcohol and organic acid formation pathways are able to enhance $\mathrm{H}_{2}$ yield as compared to wild type strain $\left(3.8 \mathrm{~mol} \mathrm{H}_{2} \mathrm{~mol}^{-1}\right.$ glucose). Recently, acidogenic microbial consortium obtained from the anaerobic digester is also found suitable for hydrogen production (Mishra et al. 2015).

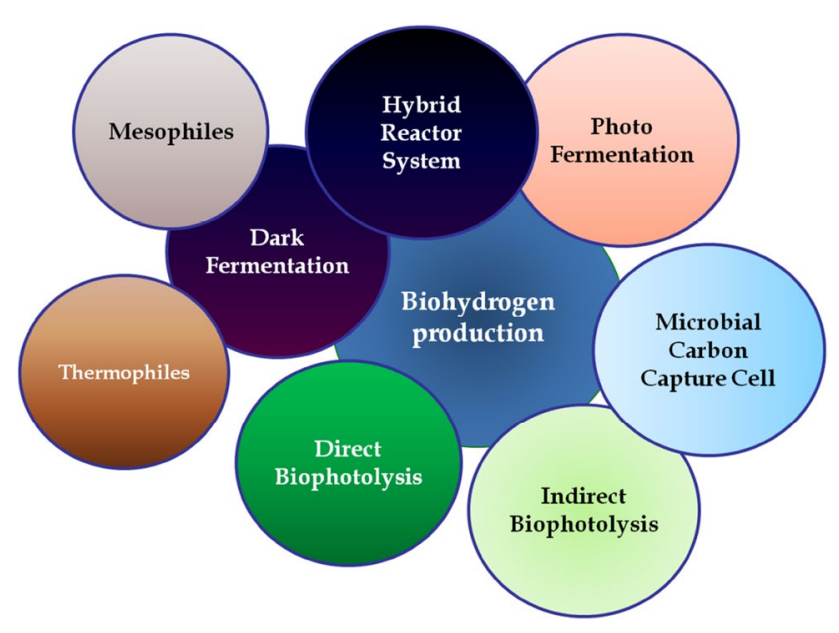

Fig. 1 Biohydrogen production processes

\section{Suitability of different organic wastes and processes on biohydrogen production}

Suitability of different organic feed stocks for hydrogen production has been studied (Sinha et al. 2016). Attempts have been made to explore the use of algal biomass, deoiled cakes, starchy wastewater, lignocellulosic biomass, cane molasses etc. as feedstock (Table 1) (Kumari and Das 2016, 2017). Usually wastewaters have tack of nutrients for the growth of the microorganisms. Effort has been made to identify cost effective nutrient rich supplement for the improvement of hydrogen production using wastewater as substrate. Use of de-oiled cakes as nitrogen supplements has been explored. The maximum cumulative hydrogen production and hydrogen yield on using de-oiled cakes are $3.2 \mathrm{~L} \mathrm{~L}^{-1}$ and $11.2 \mathrm{~mol} \mathrm{H}_{2} \mathrm{~kg}^{-1} \mathrm{COD}_{\text {removed }}$, respectively. Groundnut and coconut de-oiled cakes appear most promising as a substrate as well as nutritional supplement in the hydrogen production process. The suitability of cane molasses as substrate for continuous biohydrogen production has been demonstrated using a $20 \mathrm{~L}$ bioreactor (Roy et al. 2014a, b). The maximum rate of hydrogen production and yield achieved are $67 \mathrm{~L} \mathrm{~h}^{-1}$ and $18.54 \mathrm{~mol}$ $\mathrm{H}_{2} \mathrm{~kg}^{-1}$ COD removed, respectively. As $\mathrm{H}_{2}$ is the product of dark fermentation, its accumulation inhibits the product formation in accordance to Le Chatelier's principle. This increase in partial pressure also contributes towards metabolic shift during fermentation. It leads to formation of reduced end products such as ethanol, propionate, lactate, butanol and acetone. Many strategies are used for the removal of $\mathrm{H}_{2}$ from the fermentation system (Mandal et al. 2006). A sophisticated 'automatic logic control system' has been developed for the operation of continuous hydrogen production under reduced partial pressure conditions (Fig. 2). Reduced partial pressure always helps in improving the kinetics of hydrogen production. Maintenance of a reduced partial pressure on the overhead space of a reactor has been made automated by implementating this system. This has made the process easy to operate and also helped in improving the overall $\mathrm{H}_{2}$ yield.

A substantial research has been carried out on development of continuous hydrogen production process especially in customized bioreactors. A prototype $20 \mathrm{~L}$ packed bed reactor has also been developed for continuous hydrogen production (Fig. 3). Such type of packed bed reactor uses cheaper agro-residues as matrix for whole cell immobilization. The live demonstration of the process has been uploaded in the website: http://www.bioh2iitkgp.in.

MNRE, Government of India has already prepared a Hydrogen road map in India. IIT Kharagpur is the leading Group in India working on "Hydrogen production through biological routes" under this programme. Our endeavour 
Table 1 Biohydrogen production using different feedstock by IIT Kharagpur

\begin{tabular}{|c|c|c|c|c|c|c|c|}
\hline $\begin{array}{l}\text { Substrates/ } \\
\text { wastes }\end{array}$ & $\begin{array}{l}\text { Media composi- } \\
\text { tion with concen- } \\
\text { tration }\end{array}$ & $\begin{array}{l}\text { Process param- } \\
\text { eters (pH, Temp, } \\
\text { Agitator speed, } \\
\text { etc.) }\end{array}$ & $\begin{array}{l}\text { Mode of opera- } \\
\text { tion (batch or } \\
\text { continuous) }\end{array}$ & $\begin{array}{l}\text { Vessel (with } \\
\text { working volume) } \\
\text { (L) }\end{array}$ & $\begin{array}{l}\text { Rate of } \mathrm{H}_{2} \\
\text { production (mL } \\
\left.\mathrm{L}^{-1} \mathrm{~h}^{-1}\right)\end{array}$ & $\begin{array}{l}\text { Yield }\left(\mathrm{mol} \mathrm{H}_{2}\right. \\
\text { per kg COD } \\
\text { removed) }\end{array}$ & $\begin{array}{l}\text { Conversion } \\
\text { efficiency } \\
(\%)\end{array}$ \\
\hline \multicolumn{8}{|c|}{ Mesophilic dark fermentative hydrogen production } \\
\hline $\begin{array}{l}\text { Cheese whey } \\
65 \mathrm{~g} \mathrm{COD} / \mathrm{L}\end{array}$ & $\begin{array}{l}\text { Raw cheese } \\
\text { whey }\end{array}$ & $\begin{array}{c}37^{\circ} \mathrm{C}, 7.0 \\
180 \mathrm{rpm}\end{array}$ & Batch & $\begin{array}{l}\text { Double jacketed } \\
(300 \mathrm{~mL})\end{array}$ & 49 & 5.7 & 30 \\
\hline $\begin{array}{l}\text { Distillery } \\
\text { effluent } 60 \mathrm{~g} \\
\text { COD/L }\end{array}$ & $\begin{array}{l}\mathrm{DE}+\left(\mathrm{FeSO}_{4},\right. \\
\mathrm{MgSO}_{4}, \mathrm{CuCl}_{2} \\
\left.\mathrm{CoCl}_{2}\right)\end{array}$ & $\begin{array}{c}37^{\circ} \mathrm{C}, 7.0 \\
180 \mathrm{rpm}\end{array}$ & Batch & $\begin{array}{l}\text { Serum bottle } \\
\quad(80 \mathrm{~mL})\end{array}$ & 80 & 7.2 & $30-35$ \\
\hline $\begin{array}{l}\text { Starchy waste- } \\
\text { water } 15 \mathrm{~g} \\
\text { COD/L }\end{array}$ & $\begin{array}{l}\text { Malt and yeast } \\
\text { extract }\end{array}$ & $\begin{array}{c}37^{\circ} \mathrm{C}, 7.5 \\
180 \mathrm{rpm}\end{array}$ & Batch & $\begin{array}{l}\text { Serum bottle } \\
\quad(80 \mathrm{~mL})\end{array}$ & 70 & 6.4 & $30-40$ \\
\hline $\begin{array}{c}\text { Cane molasses } \\
10 \mathrm{~g} \mathrm{COD} / \mathrm{L}\end{array}$ & $\begin{array}{l}\text { Malt and yeast } \\
\text { extract }\end{array}$ & $\begin{array}{c}37^{\circ} \mathrm{C}, 6.5 \\
180 \mathrm{rpm}\end{array}$ & $\begin{array}{l}\text { Batch } \\
\text { Continuous }\end{array}$ & $\begin{array}{l}\text { Double jacketed } \\
\quad(500 \mathrm{~mL}) 20 \mathrm{~L} \\
\text { (SS) }\end{array}$ & 110 & $\begin{array}{l}8.2 \\
18.0\end{array}$ & $\begin{array}{l}45-55 \\
45-55\end{array}$ \\
\hline $\begin{array}{l}\text { Groundnut } \\
\text { deoiled cake }\end{array}$ & - & $\begin{array}{c}37^{\circ} \mathrm{C}, 6.5 \\
180 \mathrm{rpm}\end{array}$ & Batch & $\begin{array}{l}\text { Serum bottle } \\
(80 \mathrm{~mL})\end{array}$ & - & 11.2 & - \\
\hline $\begin{array}{l}\text { Coconut } \\
\text { deoiled cake }\end{array}$ & - & $\begin{array}{c}37^{\circ} \mathrm{C}, 6.5 \\
180 \mathrm{rpm}\end{array}$ & Batch & $\begin{array}{l}\text { Serum bottle } \\
\quad(80 \mathrm{~mL})\end{array}$ & - & 9.2 & - \\
\hline $\begin{array}{l}\text { Mustard } \\
\text { deoiled cake }\end{array}$ & - & $\begin{array}{c}37^{\circ} \mathrm{C}, 6.5 \\
180 \mathrm{rpm}\end{array}$ & Batch & $\begin{array}{l}\text { Serum bottle } \\
\quad(80 \mathrm{~mL})\end{array}$ & - & 8.8 & - \\
\hline \multicolumn{8}{|c|}{ Thermophilic dark fermentative hydrogen production } \\
\hline $\begin{array}{c}\text { Cane molasses } \\
10 \mathrm{~g} \mathrm{COD} / \mathrm{L}\end{array}$ & DSMZ140 & $\begin{array}{c}60^{\circ} \mathrm{C}, 6.5 \\
180 \mathrm{rpm}\end{array}$ & $\begin{array}{l}\text { Batch } \\
\text { Continuous }\end{array}$ & $\begin{array}{l}\text { Double jacketed } \\
(250 \mathrm{~mL})\end{array}$ & $\begin{array}{l}329 \\
1646\end{array}$ & 14.5 & $\begin{array}{l}52 \\
58\end{array}$ \\
\hline $\begin{array}{l}\text { Distillery } \\
\text { effluent } 60 \mathrm{~g} \\
\text { COD/L }\end{array}$ & DSMZ 140 & $\begin{array}{c}60^{\circ} \mathrm{C}, 6.5 \\
180 \mathrm{rpm}\end{array}$ & Batch & $\begin{array}{l}\text { Double jacketed } \\
\quad(500 \mathrm{~mL})\end{array}$ & 84 & 6.2 & 66 \\
\hline $\begin{array}{l}\text { Starchy waste- } \\
\text { water } 18 \mathrm{~g} \\
\mathrm{COD} / \mathrm{L}\end{array}$ & DSMZ 140 & $\begin{array}{c}60^{\circ} \mathrm{C}, 6.5 \\
180 \mathrm{rpm}\end{array}$ & $\begin{array}{l}\text { Batch } \\
\text { Continuous }\end{array}$ & $\begin{array}{l}\text { Double jacketed } \\
\quad(500 \mathrm{~mL})\end{array}$ & $\begin{array}{l}800 \\
1420\end{array}$ & $\begin{array}{l}11.2 \\
12.6\end{array}$ & $\begin{array}{l}54 \\
55\end{array}$ \\
\hline $\begin{array}{l}\text { Algal biomass } \\
2 \mathrm{~g} \mathrm{COD} / \mathrm{L}\end{array}$ & DSMZ 140 & $\begin{array}{c}60^{\circ} \mathrm{C}, 6.5 \\
180 \mathrm{rpm}\end{array}$ & Batch & $\begin{array}{l}\text { Double jacketed } \\
(500 \mathrm{~mL})\end{array}$ & - & 3.2 & 54 \\
\hline \multicolumn{8}{|c|}{ Photofermentation (R. sphaeroides OU001) } \\
\hline $\begin{array}{l}\text { Mixed sub- } \\
\text { strate } 5 \mathrm{~g} \\
\mathrm{COD} / \mathrm{L}\end{array}$ & $\begin{array}{l}\text { Acetate, butyrate } \\
\text { and ethanol }\end{array}$ & $\begin{array}{l}\mathrm{pH} 7.0,32.5^{\circ} \mathrm{C}, \\
180 \mathrm{rpm}, \\
10.25 \mathrm{~W} / \mathrm{m}^{2}\end{array}$ & Batch & $\begin{array}{l}\text { Annular photo } \\
\text { bioreactor } \\
(1 \mathrm{~L})\end{array}$ & - & 5.9 & 78 \\
\hline
\end{tabular}

with large scale biohydrogen production has motivated us to commercialize biohydrogen production process for decentralized energy solution. Supplementation of groundnut de-oiled cake with different organic wastes has been investigated in a lab scale experiment in order to study the potentiality of $K$. pneumoniae as well as acidogenic culture of anaerobic digester for hydrogen production. The maximum cumulative hydrogen production and yield of $3.3 \mathrm{~L} \mathrm{~L}^{-1}$ and $10.2 \mathrm{~mol} \mathrm{H}_{2} \mathrm{~kg}^{-1} \mathrm{COD}_{\text {removed }}$, respectively are obtained using cane molasses supplemented with groundnut de-oiled cake in the $50 \mathrm{~L}$ bioreactor. The feasibility study on scaling-up of the biohydrogen production process using cane molasses supplemented with groundnut de-oiled cake is further studied in the pilot scale of $10 \mathrm{~m}^{3}$ reactor (Fig. 4). Live demonstration of 10,000 L reactor has been uploaded in the website: http://www. bioh2iitkgp.in. Cumulative gas production $\left(\mathrm{H}_{2}\right.$ and $\left.\mathrm{CO}_{2}\right)$ of $158.9 \mathrm{~m}^{3}$ is observed from $10 \mathrm{~m}^{3}$ of production media in $25 \mathrm{~h}$ at $34-37^{\circ} \mathrm{C}$. Total cumulative hydrogen production of $76.2 \mathrm{~m}^{3}$ is achieved. Ethanol, acetate and butyrate are the most dominant end metabolites were obtained from the spent media. Hydrogen production using organic wastes/ residues could become a promising way for economical and sustainable clean energy generation which also leads to waste management.

Mathematical modeling and simulation on the biohydrogen production processes has been carried out (Nath and Das 2011). The efficiency of biohydrogen production can be analyzed by defined mathematical models. These models also increase understanding the effect of substrate concentration, feedback inhibition, and effect of different substrates on hydrogen production. The kinetic parameters determined 


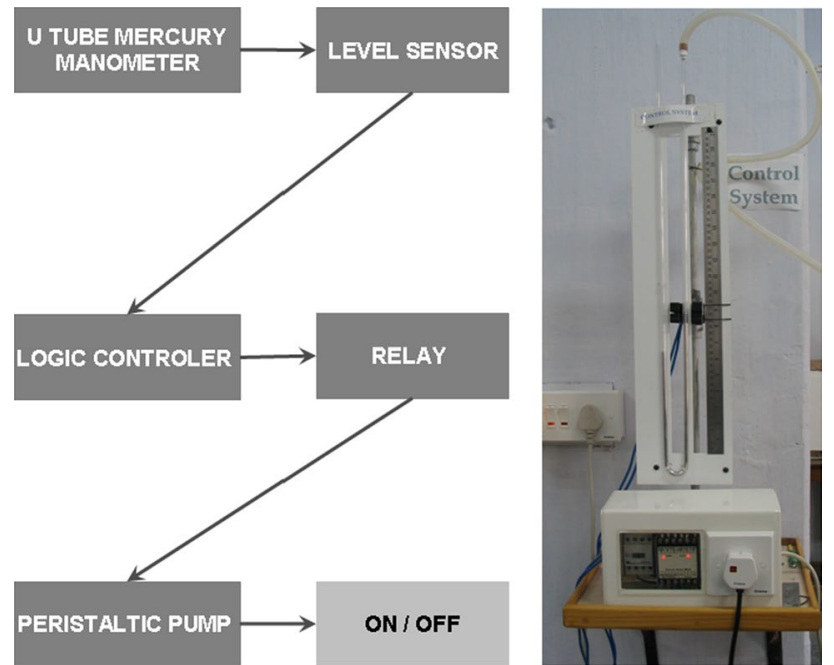

Fig. 2 Automatic logic control system for maintenance of reduced partial pressure operation of continuous hydrogen production developed by IIT Kharagpur

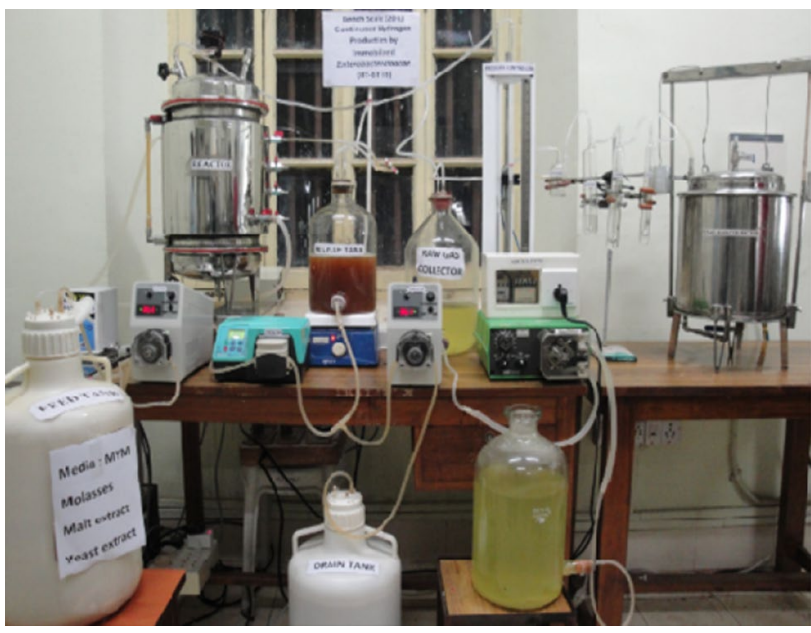

Fig. 320 L Prototype mole for demonstration of continuous biohydrogen production at Department of Biotechnology, IIT Kharagpur

from unstructured mathematical models could help in designing and scaling up of bioreactors. During $\mathrm{H}_{2}$ production, kinetics of biomass formation and products (hydrogen, VFA, solvents, etc.) are needed to be studied. Our potent microorganism, $K$. pneumonia IITBT08 has been extensively studied for biohydrogen production. Mathematical modeling using Lineweaver-Burk equation shows that it has maximum specific growth rate, $\mu_{\max }$ and saturation constant, $\mathrm{K}_{\mathrm{s}}$ of $0.28 \mathrm{~h}^{-1}$ and $0.98 \mathrm{~g} \mathrm{~L}^{-1}$, respectively. Biohydrogen production by K. pneumonia IITBT08 is growth associated product and this fact has been established by using Luedeking-Piret model. The kinetics of hydrogen production by K. pneumonia IITBT08 has been analyzed using modified Gompertz

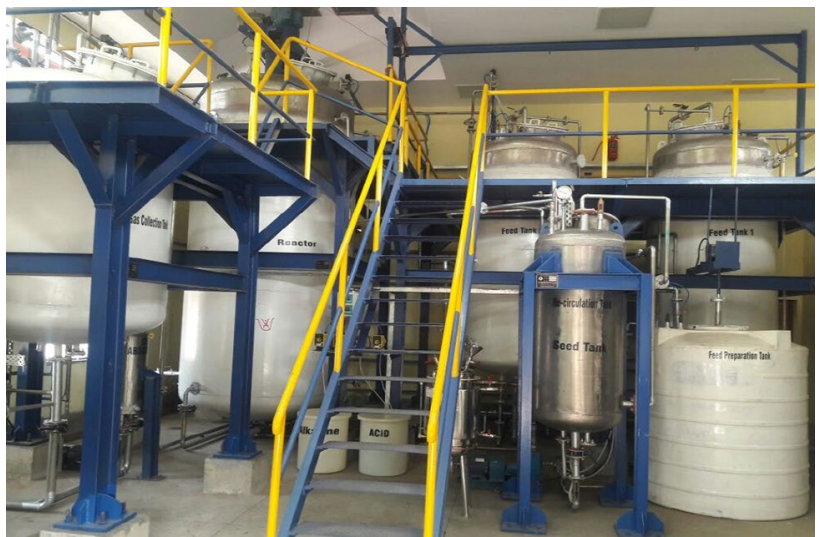

Fig. 4 10,000 L pilot plant for biohydrogen production at Department of Biotechnology, IIT Kharagpur

model. It reveals that this organism has maximum hydrogen production potential of $2.6 \mathrm{~L} \mathrm{~L}^{-1}$ with lag phase of $45 \mathrm{~min}$.

Recently, thermophilic biohydrogen production process has been explored. Thermoanaerobacterium thermosaccharolyticum ST1 has been isolated which yielded a maximum of $2.7 \mathrm{~mol} \mathrm{H}_{2} \mathrm{~mol}^{-1}$ glucose. Use of this organism in continuous hydrogen production in packed bed reactor shows higher hydrogen yield and rates as compared to mesophilic system. A detailed continuous hydrogen production using high temperature effluent such as starchy wastewater has shown that with variation in organic loading rate, the hydrogen production improved. Another interesting observation that has been observed is the inverse relationship between NADH/NAD ${ }^{+}$ratio with rate of hydrogen production (Roy et al. 2015). NADH is the reducing equivalent that is required to produce molecular hydrogen via $\mathrm{Fe}-\mathrm{Fe}$ hydrogenase pathway. Mutants have been developed that have suppressed competing pathways and higher pool of NADH for the improvement of hydrogen production.

The spent media generated after completion of dark fermentative hydrogen production is generally rich in short chain fatty acids such as acetate, butyrate, propionate etc. The energy trapped in these metabolized can be used to further improve gaseous energy recovery by integrating it with photofermentation process. Many innovative technologies in the field of photofermentative hydrogen production have been developed. One such innovation is development of a rocking flat panel reactor for photofermentation (Fig. 5). Rhodobacter sphaeroides O.U. 001 is capable of producing biohydrogen via photofermentation. Maximum hydrogen production rate of $11 \mathrm{~mL} \mathrm{~L}^{-1} \mathrm{~h}$ is observed using spent media (Nath and Das 2009).

Recently, research work has also been carried out to explore the possibility of integrating biohydrogen production process with biomethanation under the eponym of Biohythane (Fig. 6). This process shows promise in improving 


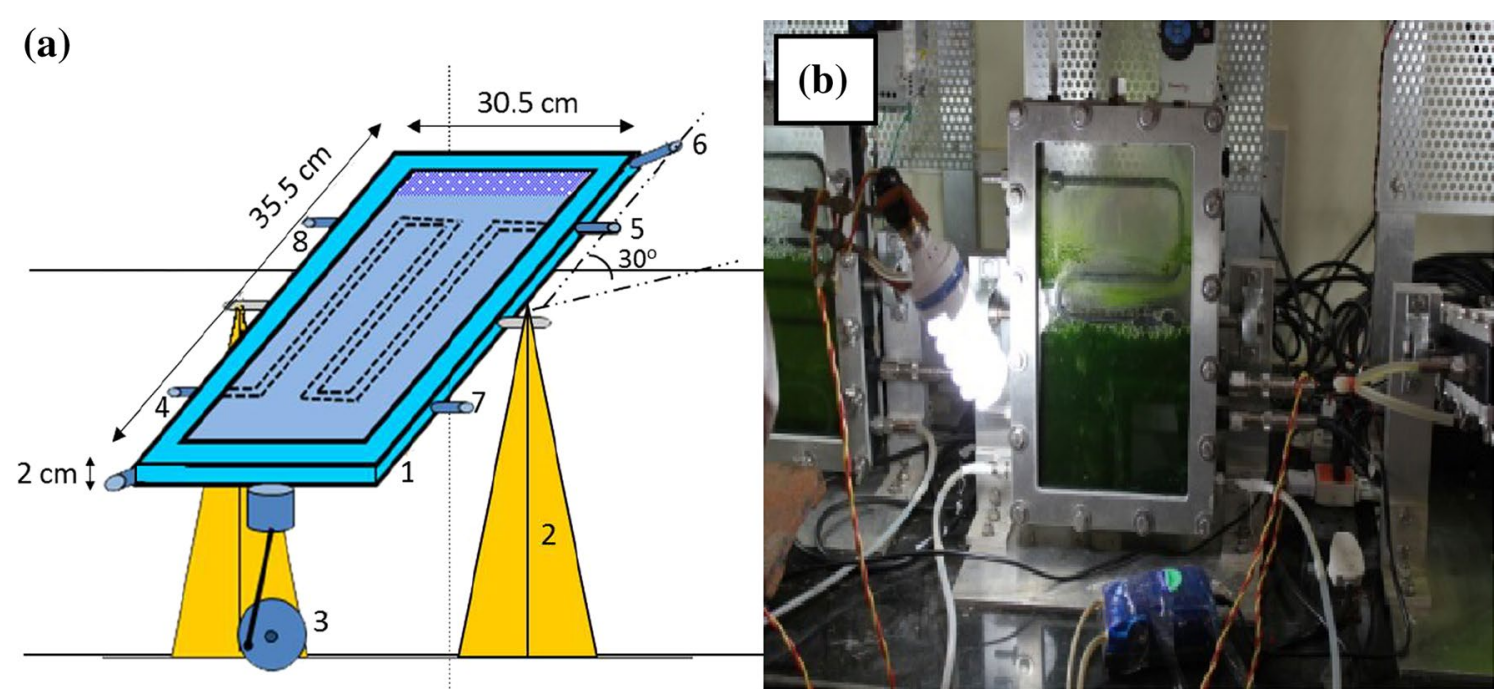

Fig. 5 a Schematic diagram of the flat panel rocking reactor (FPBR) for photofermentation developed by IIT Kharagpur; b experimental set-up of the FPBR

Fig. 6 Schematic representation of biohythane process

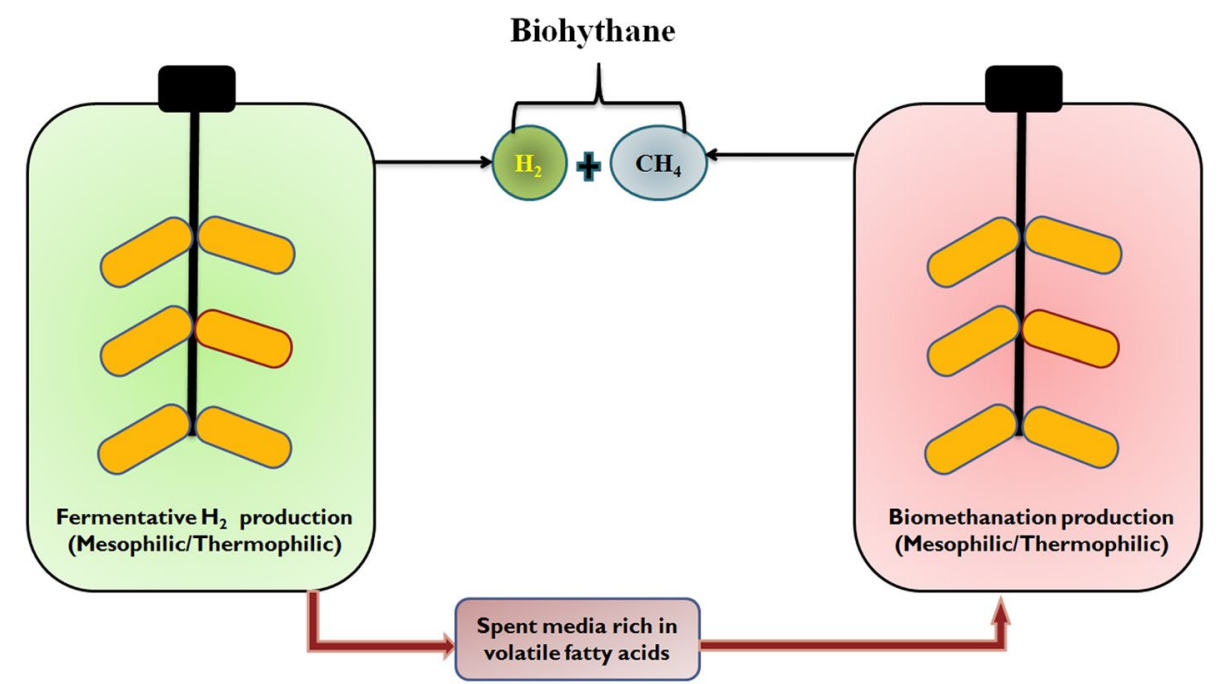

gaseous energy recovery through biological routes (Roy and Das 2016). By implementation of such two stage process, it is possible to improve gaseous energy recovery up to $56 \%$ as compared to single stage hydrogen production process.

In recent years, sequestration of atmospheric $\mathrm{CO}_{2}$ by cyanobacteria and green algae have been receiving increased attention (Kumar et al. 2014). Algal cultivation for $\mathrm{CO}_{2}$ sequestration has many advantages such as faster growth rates and the possibility of cultivation on non-arable land areas or in lakes or the ocean. Finally, an integrated approach using microbial fuel cells (MFCs) for generation of electricity from wastes can be a giant step for mankind into a sustainable future. Green algae and cyanobacteria are the vast group of both facultative photoautotrophic and photoheterotrophic microorganisms. Microalgae can be cultivated under aqueous conditions ranging from freshwater to situations of extreme salinity and from controlled closed system to open system. Algae are generally classified into several taxonomic groups on the basis of their nature and properties, type, number and morphology of flagella, reverse food products chemistry and product of photosynthesis, their chemical and physical properties of cell walls, morphological characteristics of cells and mode of reproduction etc. Their uniqueness that separates them from other microorganisms is due to presence of chlorophyll and having photosynthetic ability in a single algal cell, therefore, allowing easy operation for biomass generation, and effective genetic and metabolic research in a much shorter time period than conventional plants. The algal biorefinery concept has also been explored (Eldin et al. 2014). The efforts are concentrated on high rate algal biomass generation in controlled photobioreactors with subsequent use of the obtained biomass as a source of food, 
feed, biofuels and bioactive compounds (Fig. 7). In continuous mode of operation with Chlorella sorokiniana, the maximum biomass productivity of $0.11 \mathrm{~g} \mathrm{~L}^{-1} \mathrm{~h}^{-1}$ is observed at an optimum dilution rate of $0.05 \mathrm{~h}^{-1}$ using $5 \%$ air- $\mathrm{CO}_{2}(\mathrm{v} / \mathrm{v})$ gas mixture. Biological fixation of $\mathrm{CO}_{2}$ has been also studied using industrial flue gas (Kumar et al. 2014). The flue gas emitted from the oil producing industry contains mostly $\mathrm{CO}_{2}$ and $\mathrm{H}_{2} \mathrm{~S}\left(15.6 \% \mathrm{v} / \mathrm{v}\right.$ and $120 \mathrm{mg} \mathrm{L}^{-1}$, respectively) along with nitrogen, methane, and other hydrocarbons.

The highest reduction in the $\mathrm{CO}_{2}$ content of inlet flue gas is $4.1 \%(\mathrm{v} / \mathrm{v})$. Cyanobacteria are also used for $\mathrm{CO}_{2}$ sequestration study. Anabaena sp. PCC 7120 is grown in customized airlift photobioreactors. Higher light utilization efficiency and a higher rate of $\mathrm{CO}_{2}$ biofixation are observed with maximum biomass concentration of $0.71 \mathrm{~g} \mathrm{~L}^{-1}$ using BG11 medium under aerated conditions (Nayak et al. 2014). Another new approach for $\mathrm{CO}_{2}$ sequestration is microbial carbon capture cells (MCCs) (Pandit et al. 2012). Cyanobacteria have been grown in photo biocathode in dual-chambered flat plate mediator-less MFCs which is separated by an anion exchange membrane. The performance of the MCC with Anabaena purged with $\mathrm{CO}_{2}$-air mixture is compared with that of a conventional cathode purged with air only. It has been established that light can efficiently penetrate up to $3 \mathrm{~cm}$ on giving external illumination. Hydrogen production from algal cultivation has been explored via two distinct technologies. Firstly, use of photo biological process of algae for hydrogen production shows maximum hydrogen production rate of $1 \mathrm{~mL} \mathrm{~L}^{-1} \mathrm{~h}$ by using Chlorella sorokiniana. Similar studies with cyanobacteria, Anabena sp. also has shown slower hydrogen production rates. Second strategy of hydrogen production from algal biomass is to use it as feedstock for dark fermentation. The algal biomass are generally rich in carbohydrates such as starch, cyanophycean starch etc. which can be a potential source of fermentable sugars. Highest hydrogen yield of $2.67 \mathrm{~mol} \mathrm{~mol}^{-1}$ of hexose is observed by using $C$. sorokiniana biomass as feedstock.

The advent of microbial fuel cell (MFC)-based technologies have turned out to be promising technologies for direct energy production from various wastewaters. MFCs can utilize organic substrates and subsequently convert their chemical energy to electricity in a single step using microorganisms. MFC is a bio-electrochemical reactors/device typically consists of anode and cathode chambers physically separated by a proton exchange membrane (PEM). A MFC can be divided into three major components, namely an anaerobic anode chamber, an aerobic cathode chamber and an ion exchanger connecting the two chambers (Fig. 8). Anode chamber is the microbial growth compartment, which provides all the necessary condition for the growth and the electron extraction from the microorganism (Varanasi et al. 2016). The chamber is fed with growth media named as anolyte, redox mediator (not required in case of mediatorless MFC), microorganism and an electrode that acts as the anode of the MFC. The bacterial growth in this chamber produces the necessary protons and electrons through metabolic reactions. However, numerous hurdles need to be overcome to make this technology economically feasible and suitable for field applications.

Extensive research work has been carried out on MFC process and focused to improve the performance, reduce the construction cost, and expand the application scopes
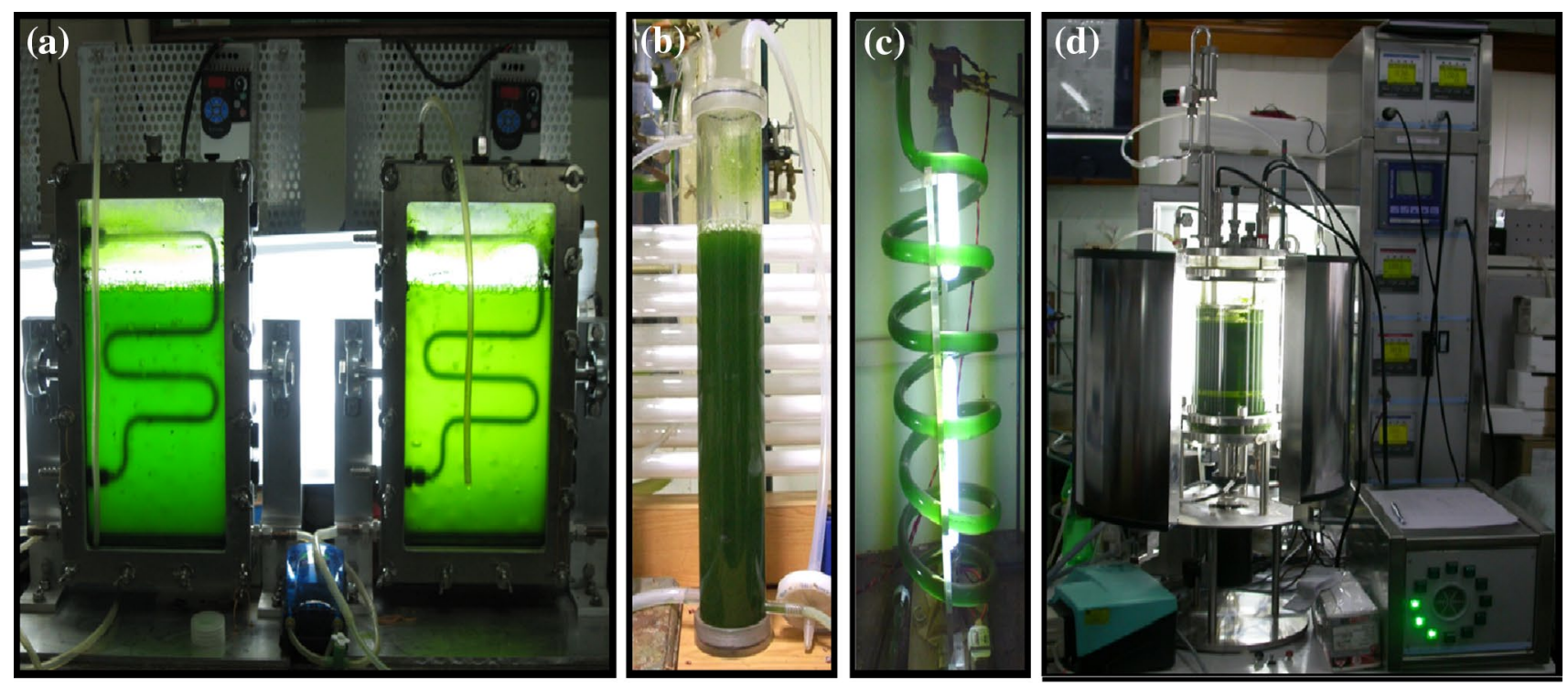

Fig. 7 Photobioreactors for used for algal cultivation in IIT KGP: a flat panel reactor; $\mathbf{b}$ air lift reactor; $\mathbf{c}$ helical tubular reactor; and $\mathbf{d}$ controlled stirred tank fermentor 
Fig. 8 Microbial Fuel cells used for electricity generation from wastewater in IIT KGP a H-type dual chamber MFC; $\mathbf{b}$ stackable MFC
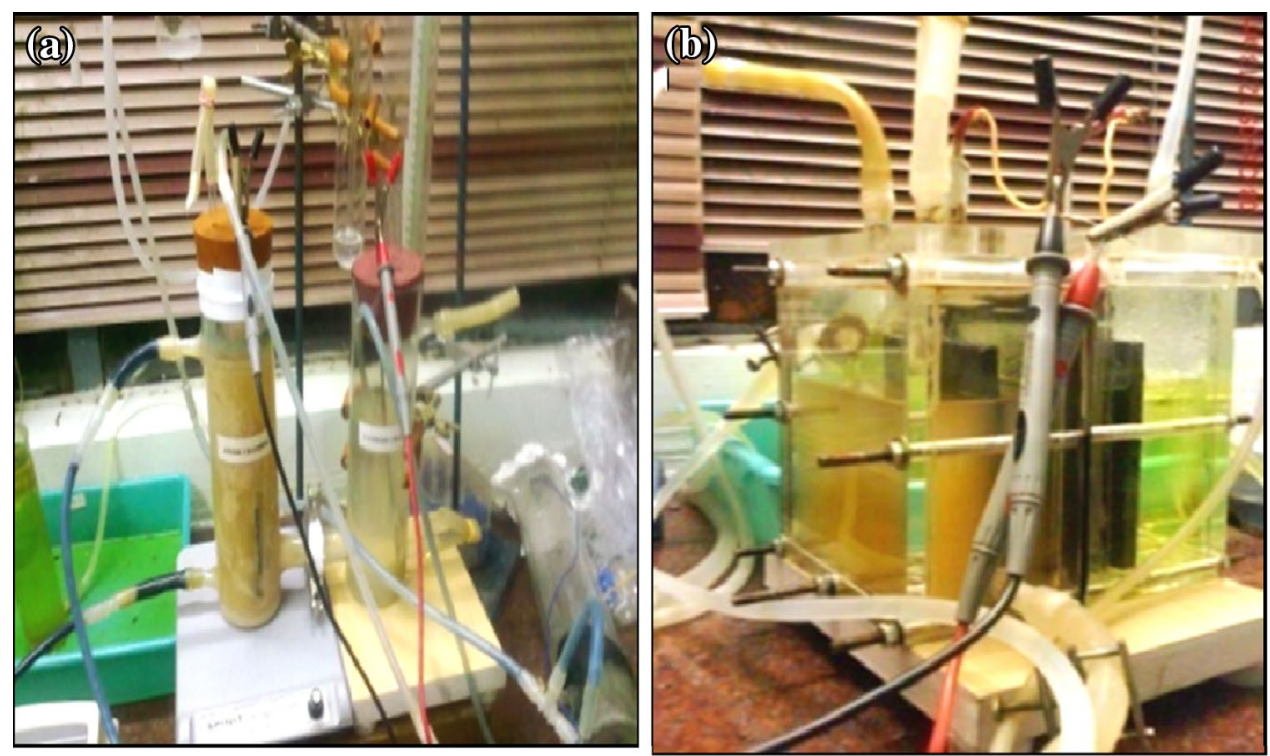

of MFC based technologies collectively known as bioelectrochemical systems. Low cost materials for the anode, cathode and membrane in MFCs are studied to increase the power performance using complex wastewaters as substrate. Catalytic enhancement with $\mathrm{MnCo}_{2} \mathrm{O}_{4}$ in presence of polypyrrole (PPy) on carbon cloth cathode shows maximum potential reaching power densities of $10.2 \mathrm{~W} \mathrm{~m}^{-3}$ using low cost $\mathrm{KOH}$ doped PVA-PDDA anion exchange membrane. The developed MFC system has been explored for hydrogen production under microbial electrochemical system. The developed biofilm on anode during MFC regime would augment towards the poised potential provided to the cathode. At cathode the proton generated during MFC regime may be converted to molecular hydrogen. The rate of hydrogen production from such system is found to be $10 \mathrm{~mL} \mathrm{~L}^{-1} \mathrm{~h}$ (Varanasi et al. 2017).

\section{Conclusion}

Suitability of different biohydrogen production processes has been explored. K. pneumonia IIT-BT 08 is found suitable for $\mathrm{H}_{2}$ production using different carbon sources at $36{ }^{\circ} \mathrm{C}$ and $\mathrm{pH}$ 6.5. Double mutant strain of this microorganism and reduced partial pressure of $\mathrm{H}_{2}$ improved the gas generation significantly. Scaling up studies has been successfully carried out up to 20 and 10,000 L. Acidogenic microflora present in the anaerobic digestion process is found suitable for the $\mathrm{H}_{2}$ production. The spent medium from dark fermentation is found suitable for $\mathrm{H}_{2}$ photoproduction by $R$. sphaeroides O.U. 001 or microalgae like Chlorella sorokiniana or MFC in a two-stage batch fermentation process but $\mathrm{H}_{2}$ yield is less as compared to dark fermentation process. The possibilities of using different organic residues such as coconut de-oiled cake, sewage sludge, cane molasses, distillery effluents, starch wastes, algal biomass etc. for $\mathrm{H}_{2}$ production are explored. Continuous hydrogen production is successfully demonstrated using immobilized whole cell system using environmental friendly solid matrix. The present immobilized system may overcome some difficulties like gas hold-up, diffusion problem etc. due to the improvement of reactor configuration. Modeling and simulation studies are carried out for the different bioH $_{2}$ production processes. Biohydrogen production has been established as a prospective alternative and integral component of green sustainable energy. However, two major aspects need indispensable optimization viz. a suitable renewable organic wastes/ wastewater and ideal microbial consortia that can convert this biomass efficiently to hydrogen. Biohythane process can improve both COD reduction and gaseous energy recovery significantly indicating its potentiality to overcome the energy scarcity problem in future using organic wastes as substrate.

Acknowledgements The author gratefully acknowledge Ministry of New and Renewable Energy (MNRE-India), Defence Research and Development Organisation (DRDO_-India), and Department of Biotechnology (DBT-India) for the necessary funding for the present research work and also IIT Kharagpur for the facilities provided to conduct this research work.

\section{References}

Das D, Veziroglu TN (2001) Hydrogen production by biological processes: a survey of literature. Int J Hydrog Energy 26:13-28

Das D, Veziroglu TN (2008) Advances in biological hydrogen production processes. Int J Hydrog Energy 33:6046-6057 
Eldin J, Kumar K, Das D (2014) Physicochemical parameters optimization and purification of phycobiliproteins from the isolated Nostoc sp. Bioresour Technol 166:541-547

Kumar N, Das D (2000) Enhancement of hydrogen production by Enterobacter cloacae IIT-BT 08. Process Biochem 35(6):589-594 (Erratum 35(9):1074)

Kumar N, Ghosh A, Das D (2001) Redirection of biochemical pathways for the enhancement of $\mathrm{H}_{2}$ production by Enterobacter cloacae. Biotechnol Lett 23(7):537-541

Kumar K, Banerjee D, Das D (2014) Carbon dioxide sequestration from industrial flue gas by Chlorella sorokiniana. Bioresour Technol 152:225-233

Kumari S, Das D (2016) Biologically pretreated sugarcane top as a potential raw material for the enhancement of gaseous energy recovery by two stage biohythane process. Bioresour Technol 218:1090-1097

Kumari S, Das D (2017) Improvement of biohydrogen production using acidogenic culture. Int J Hydrog Energy 42:4083-4094

Mandal B, Nath K, Das D (2006) Improvement of biohydrogen production under decreased partial pressure of $\mathrm{H}_{2}$ by Enterobacter cloacae. Biotechnol Lett 28:831-835

Mishra P, Roy S, Das D (2015) Comparative evaluation of the hydrogen production by mixed consortium, synthetic co-culture and pure culture using distillery effluent. Bioresour Technol 198:593-602

Nath K, Das D (2009) Effect of light intensity and initial pH during hydrogen production by an integrated dark and photofermentation process. Int J Hydrog Energy 34:7497-7501

Nath K, Das D (2011) Modeling and optimization of fermentative hydrogen production. Bioresour Technol 102:8569-8581
Nayak BK, Roy S, Das D (2014) Biohydrogen production from algal biomass (Anabaena sp. PCC 7120) cultivated in airlift photobioreactor. Int J Hydrog Energy 39:7553-7560

Pandit S, Nayak B, Das D (2012) Microbial carbon capture cell using cynobacteria for simultaneous power generation, carbon dioxide sequestration and wastewater treatment. Bioresour Technol 107:97-102

Roy S, Das D (2016) Biohythane production from organic wastes: present state of art. Environ Sci Pollut Res 23:9391-9410

Roy S, Kumar K, Ghosh S, Das D (2014a) Thermophilic biohydrogen production using pretreated algal biomass as substrate. Biomass Bioenergy 61:157-166

Roy S, Vishnuvardhan M, Das D (2014b) Continuous thermophilic biohydrogen production in packed bed reactor. Appl Energy 136:51-58

Roy S, Banerjee D, Dutta M, Das D (2015) Metabolically redirected biohydrogen pathway integrated with biomethanation for improved gaseous energy recovery. Fuel 158:471-478

Sinha P, Roy S, Das D (2016) Genomic and Proteomic approaches for dark fermentative biohydrogen production. Renew Sustain Energy Rev 56:1308-1321

Varanasi JL, Nayak AK, Sohn Y, Pradhan D, Das D (2016) Improvement of power generation of microbial fuel cell by integrating tungsten oxide electrocatalyst with pure or mixed culture biocatalysts. Electrochim Acta 199:154-163

Varanasi JL, Kumari S, Das D (2017) Improvement of energy recovery from water hyacinth by using integrated system. Int J Hydrog Energy. https://doi.org/10.1016/j.ijhydene.2017.11.110 